\title{
Identifying the Wood of Historic Artefacts: Basic Information or Simply a Curiosity?
}

\author{
Nicola Macchioni* and Mauro Bernabei \\ CNR - IVALSA, National Research Council of Italy - Trees and Timber Institute, Italy
}

Submission: August 09, 2018; Published: August 16, 2018

*Corresponding author: Nicola Macchioni, CNR - IVALSA National Research Council of Italy - Trees and Timber Institute, Italy; Tel: +39 3355425776; Email: macchioni@ivalsa.cnr.it

Keywords: Historic; Artefacts; Curiosity; Wood; Humans; Dendrochronological; Oxygen; Degrading organisms; Table painting; Venetian carpenters; Sociological; Museums; Archaeological wood; Waterlogged

\section{Mini Review}

It is well known that wood is one of the most important raw materials used by humans during their entire evolutionary history. There are not many wooden finds that have come down to us from prehistory. But it is however documented that since the Neanderthal era humans were able to work wood to obtain tools, even if their purposes are not always clear to us [1-3]. The archaeological excavations have unearthed numerous artefacts from the historical era of both dry archaeological wood and waterlogged archaeological wood [4]. Although wood is a biodegradable material, in spite of this, in very distant and harsh environments, wood has been able to preserve itself as a very dry material or as a waterlogged material, where oxygen deficiency has limited or slowed down the activity of degrading organisms.

This is evidenced by the numerous wooden artefacts preserved in all the collections of Egyptian museums around the world [5-8], or by the findings already musealized or in the course of musealization coming from underwater or terrestrial excavations below the water table, from the era of Roman Republic and until the Modern Age [8-11].

Finally, all the museums, the ancient palaces, the churches are full of artefacts entirely or partially made of wood, fundamental for the historical-artistic study of all the civilizations. A famous example from the Western civilisation, the Mona Lisa is painted on two planks of poplar wood [12]. It is also important to underline that for several civilisations the use of specific timbers could also take ritual meanings [13]. Despite the great availability of case studies, wood is the least characterised raw material in the field of cultural heritage. The amount of scientific work published in specialized journals is rather small, especially when compared with the quantity of artefacts hypothetically available. That is to say that the characterization of the raw material used for the realization of wooden artefacts important for the historical-artistic study is rarely performed.

For example, those who visit in any museum collections of different types of artefacts can find at best the indication "wood" in the case of a wooden artefact, or "table painting". While we all know that Michelangelo's David is carved not simply on stone, but on marble. The first basic characterization for wood is the timber identification. The CNR-IVALSA has worked to identify the wood species used for the carving of the statues preserved in the collection of the National Museum of Palazzo Venezia, in Rome [14]. It is more than 150 artefacts; only in two cases was the wood species indicated and we know now that in both the indication was wrong.

Two questions arise from this analysis: why are wood studies in cultural heritage so rare? Is not it that the characterization of the raw material, starting from the identification of the species, is perhaps not so important for the conservation and study of the wooden artefacts? The answer to the first question is probably that wood technologists are not numerous. Wood technologists who have experience in the characterization of artefacts of historical and artistic heritage are even less. Furthermore, the characterization of wood requires an interdisciplinary approach. The wood technologist is not enough, but the anatomical analyses, the physical-mechanical, the chemical ones are necessary. The opinion of the biological degradation specialist is also needed and the dating too. There are few laboratories able to offer such a wide range of knowledge on wood. Therefore, those who need to perform such investigations have no facility in finding who is able to perform them in a reliable manner. 
To the second question I would like to answer with an example, the preliminary studies that have informed the restoration of the roof structure of the Nativity church in Bethlehem, Palestine. Given the problems of conservation of the wooden structure covering the Basilica, it was at the time required to carry out a series of diagnostic investigations on the different structural components of the entire building $[15,16]$. Those on the timber structure have concerned the wood identification, the structural characterization and the analysis of the degradation of the roof members through a diagnostic investigation according to the Italian standard UNI 11119:2004. Finally, the dating of the structural members was performed through the dendrochronological methodology or, alternatively, with the C14 method.

The results obtained allowed first of all to supply, as requested, the information necessary for the design of the structural restoration [17]. In fact, the causes that led to the biological degradation of the wood have been identified, in order to remedy it before restoration and during the restoration. Information has been provided on the mechanical performances of the members, which derive from the wood species and the analysis of the defects; on the presence, nature and extent of biological degradation; on the characterization of mechanical joints [18]. On the basis of all the information, a low impact and respectful restoration of the original structure was designed and carried out. Knowing the wood species it was possible to find and set up the suitable material for the construction of structural prostheses.

These can be considered basic results necessary for restoration. But the results obtained have allowed us to have interesting elements for the historical study of one of the most important buildings of Christianity [19]. The identifications of timbers and dendrochronological and C14 datings have allowed to shed light on the different phases of construction, restoration and maintenance of the building and in particular of roof carpentry $[20,21]$. The lintels of Lebanon cedar wood are dated in the Justinian era and confirm that the basilica was built between the 6th and 7th centuries AD and not based on the building erected under Constantine, which was destroyed during a revolt.

The other members allowed, through their dating, to determine that at the time of the Crusades a reconstruction/ restoration of the roof structure had taken place. Theinterventions carried out subsequently required the supply of wood by import (the Lebanon cedar was no longer available?). First the alpine larch in the rebuilding of the roof between XV and XVI century by Venetian carpenters, later the deciduous oak during the first half of the nineteenth century. The dendrochronological analysis also informs us that the larch came from the valleys of Trentino, on the Italian side of the Alps, while the oak came from Anatolian forests.
The careful analysis of the structural typologies indicates an important influence of the Venetian carpenters: the structural joint between the king-post and the tie-beam in the trusses is typically Venetian. The anchoring structure of the current roof structure to the side walls is instead clearly influenced by the earthquake-resistant experience of the populations living and building along the Izmir fault. Within this single, albeit important, case study, each of the quickly listed information would open autonomous windows of study, with historicalsociological implications. So, to conclude, the identification of timber species is just a simple academic curiosity?

\section{References}

1. Thieme H (1997) Lower Palaeolithic hunting spears from Germany. Nature 385(6619): 807-810.

2. Balme J, Bowdler S (2006) Spear and digging stick: The origin of gender and its implications for the colonization of new continents. Journal of Social Archaeology 6(3): 379-401.

3. Aranguren B, Revedin A, Amico N, Cavulli F, Giachi G, et al. (2018) Wooden tools and fire technology in the early Neanderthal site of Poggetti Vecchi (Italy). Proceedings of the National Academy of Sciences.

4. Rowell RM, Barbour RJ (1990) Archaeological wood. Properties, chemistry, and preservation. Archaeological wood. Includes dry and waterlogged wood. Papers include: Hoffman P, Jones (Eds.), MA Structure and degradation process for waterlogged archaeological wood p. 35-65.

5. Lucas A, Harris J (2012) Ancient Egyptian materials and industries. Courier Corporation.

6. Gale R, Cutler DF (2000) Plants in archaeology: identification manual of vegetative plant materials used in Europe and the Southern Mediterranean to c. 1500. Westbury and Royal Botanic Gardens, Kew.

7. Gale R, Gasson P, Hepper N, Killen G (2000) Wood: Ancient Egyptian Materials and Technology. Cambridge, USA, pp. 334-371.

8. Giachi G, Guidotti MC, Lazzeri S, Sozzi L, Macchioni N (2016) Wood identification of the headrests from the collection of the Egyptian Museum in Florence. Journal of Archaeological Science: Reports 9: 340-346.

9. Ljungdahl J (2006) Structure and properties of Vasa oak. Doctoral dissertation, KTH.

10. Pulak C, Ingram R, Jones M (2015) Eight Byzantine Shipwrecks from the Theodosian Harbour Excavations at Yenikapı in Istanbul, Turkey: an introduction. International Journal of Nautical Archaeology 44(1): 39-73.

11. Macchioni N, Pizzo B, Capretti C, Pecoraro E, Sozzi L, et al. (2016) New wooden archaeological finds from Herculaneum: the state of preservation and hypothesis of consolidation of the material from the house of the relief of Telephus. Archaeometry 58(6): 1024-1037.

12. Gril J, Ravaud E, Uzielli L, Dupré JC, Perre P, et al. (2006) Mona Lisa saved by the Griffith theory: Assessing the crack propagation risk in the wooden support of a panel painting. In International Conference on Integrated Approach to Wood Structure, Behavior and Applications p. 1-6.

13. Bontadi J, Bernabei M (2016) Inside the Dogon Masks: The Selection of Woods for Ritual Objects. IAWA Journal 37(1): 84-97.

14. Macchioni N, Fachechi GM, Lazzeri S, Sozzi L (2015) Timber species and provenances of wooden sculptures. Information from the collections of 
the National Museum of Palazzo di Venezia in Rome. Journal of Cultural Heritage, 16(1): 57-64.

15. Alessandri C (2012) Preface. Journal of Cultural Heritage 13 (2012): e1-e4.

16. Faella G, Frunzio G, Guadagnuolo M, Donadio A, Ferri L (2012) The church of the nativity in Bethlehem: Non-destructive tests for the structural knowledge. Journal of Cultural Heritage 13(4): e27-e41.

17. Alessandri C, Mallardo V, Pizzo B, Ruocco E (2012) The roof of the Church of the Nativity in Bethlehem: Structural problems and intervention techniques. Journal of Cultural Heritage 13(4): e70-e81.

18. Macchioni N, Brunetti M, Pizzo B, Burato P, Nocetti M, et al. (2012) The timber structures in the Church of the Nativity in Bethlehem: Typologies and diagnosis. Journal of cultural heritage 13(4): e42-e53.
19. Bacci M, Bianchi G, Campana S, Fichera G (2012) Historical and archaeological analysis of the Church of the Nativity. Journal of Cultural Heritage 13(4): e5-e26.

20. Bernabei M, Bontadi J (2012) Dendrochronological analysis of the timber structure of the Church of the Nativity in Bethlehem. Journal of Cultural Heritage, 13(4): e54-e60.

21. Giachi G, Capretti C, Lazzeri S, Sozzi L, Paci S, et al. (2017) Identification of wood from Roman ships found in the docking site of Pisa (Italy). Journal of Cultural Heritage 23: 176-184.

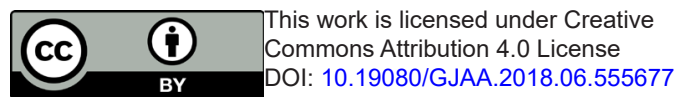

\section{Your next submission with Juniper Publishers will reach you the below assets}

- Quality Editorial service

- Swift Peer Review

- Reprints availability

- E-prints Service

- Manuscript Podcast for convenient understanding

- Global attainment for your research

- Manuscript accessibility in different formats

(Pdf, E-pub, Full Text, Audio)

- Unceasing customer service

Track the below URL for one-step submission https://juniperpublishers.com/online-submission.php 